\title{
PD-L1 expression in anogenital and oropharyngeal squamous cell carcinomas associated with different clinicopathological features, HPV status and prognosis: a meta-analysis
}

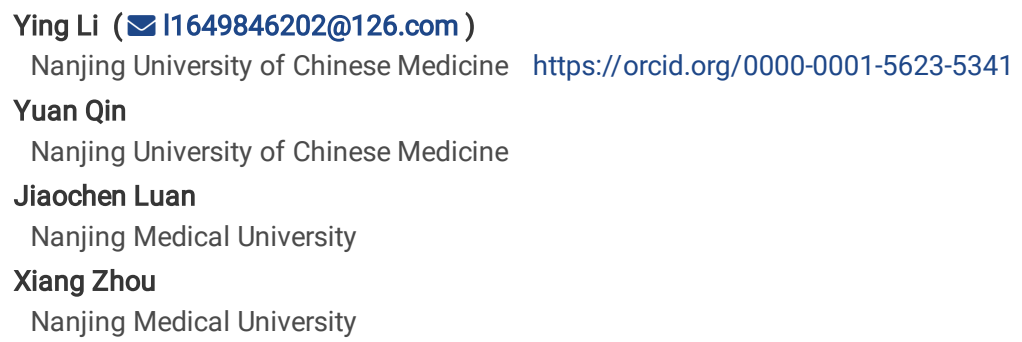




\section{Abstract}

\section{Background}

Little research has been done on clinicopathological characteristics and human papillomavirus (HPV) status of anogenital and oropharyngeal squamous cell carcinomas (SCC) with a strong expression of programmed death ligand 1 (PD-L1) in tumor cells. Therefore, we conducted this meta-analysis.

\section{Methods}

We performed a comprehensive research in PubMed, Embase and Cochrane databases up to September 30th, 2019. The effect size was hazard ratio (HR) with $95 \%$ confidence interval (Cl) for overall survival (OS), cancer specific survival (CSS), disease free survival (DFS). The pooled odds ratio (OR) with $95 \% \mathrm{Cl}$ were used to assess the association between PD-L1 expression and clinicopathological features along with HPV status.

\section{Results}

A total of 2003 cases (944 anogenital and 1059 oropharynx SCC patients) were included. High PD-L1 expression in anogenital SCC cases were associated with advanced age $(\mathrm{OR}=1.63,95 \% \mathrm{Cl}: 1.04-2.58)$ and HPV negativity $(\mathrm{OR}=0.47,95 \% \mathrm{Cl}: 0.31-0.71)$. Besides, PD-L1 positive anogenital SCC cases held a significant declined OS (HR=2.18,95\% Cl:1.37-3.47) and CSS (HR=2.45, 95\%Cl:1.30-4.65). For oropharynx SCC, PD-L1 was more frequent in younger and HPV positive patients (OR=0.60, 95\% Cl:0.37-0.98; OR=3.01, 95\% Cl:1.78-5.09) and PD-L1 expression was relevant to better OS and DFS (HR=0.76, 95\%Cl:0.60-0.97; $\mathrm{HR}=0.50,95 \% \mathrm{Cl}: 0.33-0.75)$.

\section{Conclusions}

The meta-analysis demonstrated that in anogenital SCC, PD-L1 positivity had to do with a worse outcome, which might attribute to advanced age, higher tumor grade, lymph node metastasis and HPV negativity, while in oropharynx cancer, PD-L1 expression was related to better prognosis for the reason that PDL1 was less frequent in the aged and negative HPV status.

\section{Introduction}

Human papillomavirus (HPV)-related cancers account for $8.6 \%$ of female and $0.8 \%$ of male carcinomas globally, persistent high-risk HPVs infection being the fundamental reason. High-risk HPVs not only lead to more than $80 \%$ of cervical cancer cases, but also take responsibility for approximately $88 \%$ of anal, $78 \%$ of vaginal, $51 \%$ of penile, $40 \%$ of vulvar and $30 \%$ of oropharynx cancer cases. Besides, these malignancies account for almost all of HPV-related cancers[1]. Thanks to promoting screening programs and advances in treatment of cervical lesion, the incidence and mortality rates of cervical cancer generally have declined over the last decade. However, this tendency varies in different countries and regions[2]. Among men, about 3200 new anal cancer along with 26,000 new penile cancer cases occur annually. Meanwhile, approximately 4850 new anal cancer in 2016, 6190 new vulvar cancer in 2018 and 12,000 vaginal cancer cases in 2012 were diagnosed among women worldwide[1, 3, 4].

In addition to anogenital cancers, head and neck cancer is the sixth leading cancer worldwide with 600,000 new cases per year and a mortality rate of around 450,000 per year, occupying 78\% of HPV-related oropharynx cancer cases [1,5]. Meanwhile, the HPV positive oropharyngeal cancers have been increasing during the last decade, even though the consumption of tobacco declining, especially among youngsters in more developed countries[1]. Overall, early stage HPV-related cancer patients have an optimal outcome with a high probability of cure. However, patients with advanced cancers, particularly with regional lymph nodes and distant metastases, may undergo multimodal treatments, including lymphadenectomy and chemoradiotherapy[6]. Unfortunately, these aggressive strategies can't prevent patients with high stage carcinomas from treatment failure and poor prognosis. Therefore, new effective and optimized therapeutic options for those with advanced tumors are urgent.

Recently, the efficiency of immunotherapies in certain solid tumors showed by early and late phase clinical researches brings hope for cancer patients, such as anti- programmed death 1 (PD-1) / programmed death ligand 1 (PD-L1) immunotherapy, which is one of the significant immunotherapies. And, PD-1 or PD-L1 blockade therapy is more effective than conventional therapies in advance solid tumors[7]. PD-1, a co-inhibitory receptor existing on T cells, B cells and NK cells, is combined with its ligand PD-L1 in tumor cells, which suppresses the activation and proliferation of T cells. As a result, tumor cells can escape from host anti-tumor immune. By stopping the PD-1/PD-L1 interacting with PD-1 or PD-L1 blockade therapy, cytotoxic T cells are re-stimulated to eliminate cancer cells[8]. There are many kinds of cancers expressing PD-L1, including HPV-related malignancies.

The studies investigating the association between PD-L1 expression in tumor cells and clinical characteristics in anogenital and oropharyngeal squamous cell carcinomas (SCC) are growing[9-29], which could identify potential pathological characteristics for judging whether patients could get clinical benefits from PD-1 or PD-L1 blockade therapy with variable PD-L1 expression and investigate the role of PD-L1 in anogenital and oropharyngeal SCC. However, the associations between PD-L1 expression in anogenital and oropharyngeal SCC and clinicopathological features, HPV status (i.e. based on HPV DNA, p16 overexpression, or both[30]) and prognosis are inconsistent. Therefore, we conducted the meta-analysis to clarify the association between PD-L1 expression in cancer cells and outcome, and to assess the relationship between PD-L1 expression in tumor cells and clinicopathological features along with HPV status in anogenital and oropharyngeal SCC.

\section{Methods}

\section{Literature search}


A comprehensive research was conducted in PubMed, Embase and Cochrane databases based on 'PRISMA' guidelines up to September 30th, 2019. What's more, there was no language restriction. The following items were used for searching: ("programmed cell ligand 1" or "PD-L1" or "B7-H1" or "CD274" ) and ("HPV-related" or "penile" or "penis" or "cervical" or "cervix" or "vaginal" or "vagina" or "vulvar" or "vulva" or "anal" or "anus" or "oropharyngeal" or "base of tongue" or "posterior pharyngeal wall" or "tonsil" or "soft palate" ) and ("cancer" or "tumor" or "neoplasm"). Furthermore, the references of included articles were also manually screened for other potential eligible researches.

\section{Inclusion and exclusion criteria}

Eligible studies had to fulfill the following criteria: (1) All SCC were diagnosed by pathology results. (2) PD-L1 expression was identified in tumor cells by immunohistochemistry staining. (3) The associations between PD-L1 expression and clinicopathological features, prognosis or HPV status were demonstrated in study. (4) Both HPV positive and negative patients were included in the studies. The reasons why studies were excluded were as follows: (1) No data available could be extracted from papers. (2) Studies illustrated the role of PD-L1 expressing in other cells in cancer tissues or non-SCC. (3) Patients were treated with PD-1 or PD-L1 blockade therapy. (4) Studies were non-original researches. (5) Studies only contained HPV positive or negative patients. Additionally, when the same patients occurred or were mixed in different studies, only the most recent and complete studies were included.

\section{Data extraction}

The relevant data were extracted from eligible studies by two independent authors $(X Z)$ and (JC L), which were examined by another investigator ( $Y L)$. The data extracted from the eligible studies were recorded as follows: first author, year of publication, cancer type, country of patients population, gender, age, follow-up period, patients sample size, pathology, methods for PD-L1 detection, PD-L1 distribution, cutoff value of PD-L1 positive expression, PD-L1 positive expression rate, tumor stage and outcomes of patients, including overall survival (OS), cancer specific survival (CSS), disease free survival (DFS) with hazard ratios (HR) with 95\% confidence interval $(\mathrm{Cl})$. Moreover, Newcastle-Ottawa-Scale was applied to assess the quality of included papers.

\section{Statistical analysis}

Stata software (version 12.0; Stata Corp LP, College Station, TX) was used for present meta-analysis. The relationships between PD-L1 and clinicopathological features along with HPV status were evaluated by odds ratio (OR) with $95 \%$ confidence interval (CI). If studies provided HPV-DNA and P16 status in papers, we considered that P16 was a superior biomarker to HPV-DmNA for P16 best representing oncogenic activity of the HPV in tumors[31]. Hazard ratio (HR) with 95\% Cl directly reported in eligible studies was applied to assess the role of PD-L1 in prognosis of patients, and we also adopted method described by Altman et al to calculate $95 \% \mathrm{Cl}$, when its $\mathrm{HR}$ and $\mathrm{P}$ value were provided in study[32]. Moreover, if studies offered Kaplan-Meier curves rather than $\mathrm{HR}$ with $95 \% \mathrm{Cl}$, we extrapolated $\mathrm{HR}$ with $95 \% \mathrm{Cl}$ by data directly obtained from the curves. When multivariable and univariable outcome analysis were offered, the former was adopted. Because of the obvious differences between anogenital cancers (cervical, vaginal, vulvar, penile and anal cancer) and oropharyngeal cancers in embryological origins, as well as unequivocal premalignant and malignant changes existing in entire anogenital region, we divided anogenital and oropharyngeal SCC in this meta-analysis into two main types, anogenital and oropharyngeal SCC, of which we performed meta-analysis respectively.

Heterogeneity between researches was assessed via Chi-square test and I-square test, and when value of $P \otimes 0.10$ or $I 2>50 \%$, we considered heterogeneity present in studies and used the random-effects model rather than fixed-effects model to calculate the pooled ORs/HRs. Otherwise, the fixed-effects model was applied with $p>0.10$ and $12<50 \%$. Additionally, we performed one-way sensitivity analysis to assess the stability of the results. Moreover, Egger and Begg tests were applied to evaluate the publication bias among the studies. Two-tailed $P$ values less than 0.05 were considered statistically significant.

\section{Results}

\section{Literature Search}

Initially, a sum of 570 articles were identified according to previous search strategy. Then, 328 duplications were excluded. After reviewing the title and abstract, 199 studies were removed for reasons. The full texts of the remaining articles were assessed, and 23 studies were further excluded. Eventually, we included 20 articles from the rest studies in total. A flow diagram detailing the selection process of studies was shown in Figure 1.

\section{Study characteristics}

A total of 20 studies were identified after comprehensive review and involved in the meta-analysis, which consisted of 2003 cases, including 944 anogenital SCC (246 cervical, 265 vulvar, 366 penile, 67 anal SCC cases) and 1059 oropharynx SCC patients[9-29]. All studies were retrospective and published between 2013 and 2019. Immunohistochemistry (IHC) was applied to assess the expression of PD-L1 protein, and PD-L1 positivity was defined as percent of positive tumor cells in overall cancer cells with membranous or cytoplasmic staining. The commonest cutoff value of PD-L1 positivity was $5 \%$ in the meta-analysis[10, $11,13,14,18,20,21,23,27-29]$. Furthermore, there were 3 studies combining percentage of positive cells with staining intensity as a new definition of PD-L1 positivity (H-score) $[12,17,24]$. In addition, the relationships between HPV status and PD-L1 were investigated in 8 studies of anogenital SCC[9-11, 13, 15, 17, $19,20]$, covering cervical, anal, penile and vulvar cancer cases, and 8 oropharynx SCC studies[21-26, 28, 29]. Among these researches, HPV-DNA status were considered as the biomarker of HPV oncogenic activity and were used to assess their associations with PD-L1 expression in 3 anogenital and 1 oropharynx cancer studies[11, 15, 20, 23]. Detailed characteristics of included studies were summarized in Table 1 and Table 2.

\section{PD-L1 expression and clinicopathological features}

In anogenital SCC, advanced age, higher tumor grade and lymph node metastases were related to PD-L1 positive expression (OR=1.63, 95\%Cl :1.04-2.58; $\mathrm{OR}=2.49,95 \% \mathrm{Cl}: 1.39-4.46 ; \mathrm{OR}=1.85,95 \% \mathrm{Cl}: 1.28-2.66$ ) (Table 2), demonstrated by the meta-analysis. However, no correlation was found between gender, 
tumor stage, recurrence or distant metastases and PD-L1 expression (Table 2). Contrary to anogenital SCC, PD-L1 in oropharynx SCC was less frequent in older patients (OR=0.60,95\% Cl:0.37-0.98) (Table 2). Moreover, higher tumor grade and lymph node metastases were associated with PD-L1 positive expression in oropharynx SCC (OR=3.40, 95\% Cl:1.81-6.40; OR=1.97, 95\% Cl:1.32-2.92) (Table 2). The pooled OR of 8 anogenital SCC studies showed that PDL1 negative expression was connected with HPV positivity (OR=0.47,95\% Cl:0.31-0.71, $p=0.000$ ) (Figure 2a) with a fixed effects model, and there was low heterogeneity $\left(\mathrm{I}^{2}=10.4 \%, \mathrm{p}=0.349\right)$ (Figure $\left.2 \mathrm{a}\right)$. In order to reduce heterogeneous variables among the anogenital SCC studies, subgroups of meta-analysis were performed based on cancer types, antibody catalogs and cut-off values of PD-L1 positivity. The results demonstrated that there were significant differences in the relationship between PD-L1 expression and HPV status in the groups of penile SCC, PD-L1 antibody (clone E1L3N) and cut-off value greater than or equal to $5 \%$ (Table S2).

However, PD-L1 expression was higher in HPV positive oropharynx SCC patients with moderate heterogeneity in a random effects model (OR=3.01, 95\%Cl: 1.78-5.09, $p=0.00 ; I^{2}=55.6 \%, P=0.027$ ) (Figure $2 b$ ). Stratified analysis showed that associations between high PD-L1 level and HPV positivity was significantly different in the group of antibody (clone SP142) and cut-off value greater or less than $5 \%$ (Table S2).

\section{PD-L1 expression and oncological prognosis}

In general, anogenital SCC cases that were PD-L1 positive held a significantly declined OS compared with PD-L1 negative patients (HR=2.18, 95\%Cl:1.37-3.47, $p=0.001 ; I^{2}=0.0 \%, P=0.569$ ) (Figure 3a). Subgroup analysis according to cancer types, antibody catalogs and cut-off values of PD-L1 positivity were conducted, and our meta-analysis demonstrated that the predictive value of PD-L1 expression for OS of vulvar SCC, antibody (clone 22C3) and cut-off value greater than or equal to 5\% (Table S3). Our meta-analysis also suggested that PD-L1 positive penile SCC cases held a worse CSS (HR=2.45, 95\%Cl:1.30-4.65, $\mathrm{p}=0.006 ; \mathrm{I}=45.1 \%, \mathrm{P}=0.162$ ) (Figure $3 b$ ).

In contrast to anogenital SCC, PD-L1 expression in oropharynx SCC was also a predictive value of OS $(\mathrm{HR}=0.76,95 \% \mathrm{Cl}: 0.60-0.97, \mathrm{p}=0.025 ; \mathrm{I}=0.0 \%, \mathrm{P}=0.480)$ (Figure 3c). Subgroup analysis were also conducted in accordance with antibody catalogs and cut-off values of PD-L1 positivity, and our meta-analysis suggested that the predictive value of PD-L1 expression for OS (clone SP142) and cut-off value were less than 5\% (Table S3). Meanwhile, PD-L1 expression was associated with a better DFS in oropharynx cancer patients ( $\left.\mathrm{HR}=0.50,95 \% \mathrm{Cl}: 0.33-0.75, \mathrm{p}=0.001 ; \mathrm{I}^{2}=25.8 \%, \mathrm{P}=0.260\right)$ with no substantial heterogeneity (Figure 3d).

\section{Sensitivity and publication analysis}

We again confirmed that there was low heterogeneity in studies in the present meta-analysis by sensitivity analysis. Moreover, no substantial asymmetry was identified by Egger and Begg tests in the light of the visual inspection of the shape. This indicted low publication bias and outcomes of meta-analysis was statistically robust.

\section{Discussion}

The PD-L1/PD-1 pathway has showed a remarkable value among all immune checkpoints because promising and impressing responses in many tumors, such as melanoma, non-small-cell lung cancer (NSCLC) and renal cell carcinoma, were achieved in therapies targeting the PD-1/PD-L1 pathway[33]. In HPVrelated carcinomas, antibodies targeting the PD-1/PD-L1 pathway are being assessed in oropharynx cancers, cervical cancer, penile cancer and anal cancer[34-36]. A phase $1 \mathrm{~b}$ clinical trial demonstrated that the overall response rate (ORR) of squamous cell carcinoma of the head and neck (HNSCC) cases receiving pembrolizumab was $18 \%$, and complete response was $5 \%[37]$. The antitumor activity of pembrolizumab was also shown in advance cervical cancer, whose ORR was $17 \%$ and treatment-related adverse events were acceptable[34]. Recently, a phase II trial of nivolumab in refractory metastatic anal SCC illustrated that the ORR was $21 \%[35]$. Moreover, the clinical studies exploring immunotherapy for the treatment of penile cancer are ongoing[36]. Nevertheless, not all of the cases treated with anti-PD-1/PD-L1 therapy got clinical response. Therefore, it is urgent and necessary to identify biomarkers with therapeutic effect to select patients and predict response. PD-L1 expression in tumor cells was considered as a potential response biomarker for PD-1/PD-L1 targeted therapy in most studies, including the clinical trials of nivolumab/ pembrolizumab in HNSCC, cervical and anal cancer, despite PD-L1 negative patients could also get clinical benefits from the therapy[7, 34, 35, 37]. Hence, it is necessary to clarify the role of PD-L1 in anogenital and oropharyngeal SCC, which could help to identify more suitable anogenital and oropharyngeal cancer cases for anti-PD-1/PD-L1 therapy.

In the meta-analysis of anogenital SCC, high PD-L1 expression was related to advanced age and higher tumor grade. Furthermore, PD-L1 positive patients held a worse OS in all anogenital SCC, and a worse CSS in penile SCC. PD-L1, as the dominant inhibitory ligand of PD-1, could induce a conformational change of PD1 and weaken T cell-activating signals. Consequently, proliferation, survival, cytokine production and other functions of T cell were inhibited. Additionally, signaling roles of PD-L1 molecule were identified in certain studies. PD-L1 can deliver pro-survival signals to cancer cells, leading to resistance of apoptosis. What's more, PD-L1 can prevent tumor cells from immune cytotoxic effects without assistant of PD-1 signal in T cells[33]. Therefore, the anogenital SCC become more aggressive with high PD-L1 expression, such as higher tumor grade, lymph node metastases and worse prognosis.

In HNSCC cells, IFN-y, produced by CD8 + tumor infiltrated lymphocytes (TILs), was demonstrated to control the gene expression of PD-L1 in tumor cells[28]. Higher number of CD8 + TILs or TILs were discovered in HPV positive HNSCC patients compared with HPV negative cases[28, 38]. As a result, accumulation of activated TILs and IFN-y could explain favorable outcome in PD-L1 positive HNSCC patients, which were HPV positive.

However, IFN-y, produced by TILs, seems not to be the main reason for the difference of PD-L1 expression between HPV positive and negative anogenital cancer patients, because no significant difference was identified in numbers of CD8 + TILs distributing in HPV positive and negative anal and cervical cancer patients[38, 39]. In vulvar SCC, there was fewer number of CD8 + TILs in p16 positive cases compared with p16 negative[40]. Therefore, genetic background 
(genomic aberrations and aberrant oncogenic signaling) may take the primary responsibility for PD-L1 overexpression in anogenital cancers[17, 41]. Thus PDL1 was strongly associated with advanced age, lymph node metastases and worse outcomes in SCC.

In our meta-analysis, there was a distinct association between HPV status and PD-L1 expression in oropharyngeal and non-oropharyngeal tumors, especially penile SCC. And it also might explain the relationship between PD-L1 expression and clinical outcome, as HPV-associated oropharyngeal SCC had a better clinical outcome and non-HPV-associated anogenital SCC had a worse clinical outcome. Solomon B et al[38] found that oropharynx SCC patients with high PD-L1 expression seemed to hold a worse OS compared with low PD-L1 expression cases in P16 positive patients, although results were not statistically significant in multivariable analysis ( $\mathrm{HR}=1.9,95 \% \mathrm{Cl}: 0.7-5.6)$. In addition to HPV status, the divergent relations between age of patients and PD-L1 expression could also explain that oropharyngeal SCC cases with high PD-L1 expression held a better prognosis, because PD-L1 in oropharynx SCC was more frequent in younger patients.

In order to reduce heterogeneous variables among the anogenital SCC studies, subgroups of meta-analysis were performed based on cancer types, antibody catalogs and cut-off values of PD-L1 positivity. Antibody (clone E1L3N and clone 22C3) and antibody (clone SP142) were reliable to detect PD-L1 expression in anogenital and oropharyngeal SCC respectively. Moreover, it was rational that cut-off value of PD-L1 positivity was greater than or equal to $5 \%$. Because of limited data of each cancer type in anogenital SCC, we couldn't perform meta-analysis of each kind of anogenital SCC. However, anogenital SCC (cervical, vaginal, vulvar, penile and anal cancer) had the same embryological origins, as well as unequivocal premalignant and malignant changes existing in entire anogenital region, so we considered that lumping all non-oropharyngeal tumors for meta-analysis was relatively rational.

Undoubtedly, there were some limitations in the meta-analysis. First, relatively fewer vulvar, penile and anal cancer patients were enrolled. Furthermore, no study investigating the role of PD-L1 in vaginal cancer was found after research. Therefore, clinical studies of these cancers with higher quality and large sample size are necessary to support our conclusion. Second, chemoradiotherapy also affects expression of PD-L1, but limited studies reported the detailed treatments of patients before examining the PD-L1 expression. As a result, we did not investigate the relationship between various forms of treatments and PD-L1 expression. Third, we estimated HR and 95\% Cl from Kaplan-Meier curves and with the method described by Altman et al, which were not accurate as reported by authors. Fourth, on account of limited data involving antibody catalogs of PD-L1 in HPV-related SCC, we could not judge whether different PD-L1 antibodies could lead to differing results for PD-L1 expression in HPV-related SCC. Moreover, we should highlight the lack of analytical harmonization to PDL1 evaluation, such as the consensus for p16 expression associated with HPV.

\section{Conclusions}

The results of the meta-analysis demonstrated that advanced age, higher tumor grade, lymph node metastasis and HPV negativity were associated with high PD-L1 expression in anogenital SCC cases. And anogenital SCC cases that were PD-L1 positive held a worse outcome. For oropharynx cancers, PD-L1 was less frequent in older patients and negative HPV status. Furthermore, PD-L1 expression was related to better prognosis of oropharynx cancer patients. Advanced age and negative HPV status might explain anogenital SCC cases with high PD-L1 expression holding a worse prognosis, compared with oropharynx SCC cases with high PD-L1 expression. Meanwhile, PD-L1 expression should be combined with clinicopathologic features representing high mutation load, including advanced age, higher tumor stage and HPV status, to identify more suitable HPV-related cancer cases for anti-PD-1/PD-L1 therapy.

\section{Declarations}

\section{Ethics approval and consent to participate}

The authors are accountable for all aspects of the work in ensuring that questions related to the accuracy or integrity of any part of the work are appropriately investigated and resolved.

\section{Consent for publication}

Not applicable.

\section{Availability of data and materials}

The authors state that all data supporting the findings of our study are available within the enrolled articles for meta-analysis.

\section{Competing interests}

The authors have no conflicts of interest to declare.

\section{Funding}

Not applicable.

\section{Authors' contributions}

$\mathrm{XZ}$ and JCL took part in the data extracted, statistical analysis, and drafting of the manuscript. YQ and YL helped to recheck the results and revised the manuscript. YL designed the study program and took responsibility for the integrity of the data and the accuracy of the data analysis. All authors read and approved the final manuscript. 
We gratefully thank all researchers for their contributions.

\section{References}

1. de Martel C, Plummer M, Vignat J, Franceschi S: Worldwide burden of cancer attributable to HPV by site, country and HPV type. Int J Cancer 2017, 141(4):664-670.

2. Backes DM, Kurman RJ, Pimenta JM, Smith JS: Systematic review of human papillomavirus prevalence in invasive penile cancer. Cancer Causes Control 2009, 20(4):449-457.

3. Nelson VM, Benson AB, 3rd: Epidemiology of Anal Canal Cancer. Surg Oncol Clin N Am 2017, 26(1):9-15.

4. Weinberg D, Gomez-Martinez RA: Vulvar Cancer. Obstet Gynecol Clin North Am 2019, 46(1):125-135.

5. Hoxhaj I, Hysaj O, Vukovic V, Leoncini E, Amore R, Pastorino R, Boccia S: Occurrence of metachronous second primary cancer in head and neck cancer survivors: A systematic review and meta-analysis of the literature. Eur J Cancer Care (Engl) 2020:e13255.

6. Shibata T, Lieblong BJ, Sasagawa T, Nakagawa M: The promise of combining cancer vaccine and checkpoint blockade for treating HPV-related cancer. Cancer Treat Rev 2019, 78:8-16.

7. Shen X, Zhao B: Efficacy of PD-1 or PD-L1 inhibitors and PD-L1 expression status in cancer: meta-analysis. Bmj 2018, 362:k3529.

8. Littman DR: Releasing the Brakes on Cancer Immunotherapy. Cell 2015, 162(6):1186-1190.

9. Govindarajan R, Gujja S, Siegel ER, Batra A, Saeed A, Lai K, James JD, Fogel BJ, Williamson S: Programmed Cell Death-Ligand 1 (PD-L1) Expression in Anal Cancer. Am J Clin Oncol 2018, 41(7):638-642.

10. Zhao YJ, Sun WP, Peng JH, Deng YX, Fang YJ, Huang J, Zhang HZ, Wan DS, Lin JZ, Pan ZZ: Programmed death-ligand 1 expression correlates with diminished CD8+ T cell infiltration and predicts poor prognosis in anal squamous cell carcinoma patients. Cancer Manag Res 2018, 10:1-11.

11. Heeren AM, Punt S, Bleeker MC, Gaarenstroom KN, van der Velden J, Kenter GG, de Gruijl TD, Jordanova ES: Prognostic effect of different PD-L1 expression patterns in squamous cell carcinoma and adenocarcinoma of the cervix. Mod Pathol 2016, 29(7):753-763.

12. Wang S, Li J, Xie J, Liu F, Duan Y, Wu Y, Huang S, He X, Wang Z, Wu X: Programmed death ligand 1 promotes lymph node metastasis and glucose metabolism in cervical cancer by activating integrin $\beta 4 /$ SNAI1/SIRT3 signaling pathway. Oncogene 2018, 37(30):4164-4180.

13. Udager AM, Liu TY, Skala SL, Magers MJ, McDaniel AS, Spratt DE, Feng FY, Siddiqui J, Cao X, Fields KL et al: Frequent PD-L1 expression in primary and metastatic penile squamous cell carcinoma: potential opportunities for immunotherapeutic approaches. Ann Oncol 2016, 27(9):1706-1712.

14. Deng C, Li Z, Guo S, Chen P, Chen X, Zhou Q, Chen J, Yu X, Wu X, Ma W et al: Tumor PD-L1 expression is correlated with increased TILs and poor prognosis in penile squamous cell carcinoma. Oncoimmunology 2017, 6(2):e1269047.

15. Ottenhof SR, Djajadiningrat RS, de Jong J, Thygesen HH, Horenblas S, Jordanova ES: Expression of Programmed Death Ligand 1 in Penile Cancer is of Prognostic Value and Associated with HPV Status. J Urol 2017, 197(3 Pt 1):690-697.

16. Ottenhof SR, Djajadiningrat RS, Thygesen HH, Jakobs PJ, Jóźwiak K, Heeren AM, de Jong J, Sanders J, Horenblas S, Jordanova ES: The Prognostic Value of Immune Factors in the Tumor Microenvironment of Penile Squamous Cell Carcinoma. Front Immunol 2018, 9:1253.

17. Howitt BE, Sun HH, Roemer MG, Kelley A, Chapuy B, Aviki E, Pak C, Connelly C, Gjini E, Shi Y et al: Genetic Basis for PD-L1 Expression in Squamous Cell Carcinomas of the Cervix and Vulva. JAMA Oncol 2016, 2(4):518-522.

18. Sznurkowski JJ, Żawrocki A, Sznurkowska K, Pęksa R, Biernat W: PD-L1 expression on immune cells is a favorable prognostic factor for vulvar squamous cell carcinoma patients. Oncotarget 2017, 8(52):89903-89912.

19. Hecking T, Thiesler T, Schiller C, Lunkenheimer JM, Ayub TH, Rohr A, Condic M, Keyver-Paik MD, Fimmers R, Kirfel J et al: Tumoral PD-L1 expression defines a subgroup of poor-prognosis vulvar carcinomas with non-viral etiology. Oncotarget 2017, 8(54):92890-92903.

20. Choschzick M, Gut A, Fink D: PD-L1 receptor expression in vulvar carcinomas is HPV-independent. Virchows Arch 2018, 473(4):513-516.

21. Ukpo OC, Thorstad WL, Lewis JS, Jr.: B7-H1 expression model for immune evasion in human papillomavirus-related oropharyngeal squamous cell carcinoma. Head Neck Pathol 2013, 7(2):113-121.

22. Kim HS, Lee JY, Lim SH, Park K, Sun JM, Ko YH, Baek CH, Son YI, Jeong HS, Ahn YC et al: Association Between PD-L1 and HPV Status and the Prognostic Value of PD-L1 in Oropharyngeal Squamous Cell Carcinoma. Cancer Res Treat 2016, 48(2):527-536.

23. De Meulenaere A, Vermassen T, Aspeslagh S, Deron P, Duprez F, Laukens D, Van Dorpe J, Ferdinande L, Rottey S: Tumor PD-L1 status and CD8(+) tumorinfiltrating T cells: markers of improved prognosis in oropharyngeal cancer. Oncotarget 2017, 8(46):80443-80452.

24. Steuer CE, Griffith CC, Nannapaneni S, Patel MR, Liu Y, Magliocca KR, El-Deiry MW, Cohen C, Owonikoko TK, Shin DM et al: A Correlative Analysis of PD-L1, PD-1, PD-L2, EGFR, HER2, and HER3 Expression in Oropharyngeal Squamous Cell Carcinoma. Mol Cancer Ther 2018, 17(3):710-716.

25. Fukushima Y, Someya M, Nakata K, Hori M, Kitagawa M, Hasegawa T, Tsuchiya T, Gocho T, Ikeda H, Hirohashi Y et al: Influence of PD-L1 expression in immune cells on the response to radiation therapy in patients with oropharyngeal squamous cell carcinoma. Radiother Onco/2018, 129(2):409-414.

26. Hong AM, Ferguson P, Dodds T, Jones D, Li M, Yang J, Scolyer RA: Significant association of PD-L1 expression with human papillomavirus positivity and its prognostic impact in oropharyngeal cancer. Oral Oncol 2019, 92:33-39.

27. Sato F, Ono T, Kawahara A, Kawaguchi T, Tanaka H, Shimamatsu K, Kakuma T, Akiba J, Umeno H, Yano H: Prognostic impact of p16 and PD-L1 expression in patients with oropharyngeal squamous cell carcinoma receiving a definitive treatment. J Clin Patho/ 2019, 72(8):542-549.

28. Lyford-Pike S, Peng S, Young GD, Taube JM, Westra WH, Akpeng B, Bruno TC, Richmon JD, Wang H, Bishop JA et al: Evidence for a role of the PD-1:PD-L1 pathway in immune resistance of HPV-associated head and neck squamous cell carcinoma. Cancer Res 2013, 73(6):1733-1741. 
29. Kwon MJ, Rho YS, Nam ES, Cho SJ, Park HR, Min SK, Seo J, Choe JY, Kim ES, Park B et al: Clinical implication of programmed cell death-1 ligand-1 expression in tonsillar squamous cell carcinoma in association with intratumoral heterogeneity, human papillomavirus, and epithelial-to-mesenchymal transition. Hum Pathol 2018, 80:28-39.

30. Stjernstrøm KD, Jensen JS, Jakobsen KK, Grønhøj C, von Buchwald C: Current status of human papillomavirus positivity in oropharyngeal squamous cell carcinoma in Europe: a systematic review. Acta Otolaryngol 2019, 139(12):1112-1116.

31. Venuti A, Paolini F: HPV detection methods in head and neck cancer. Head Neck Patho/ 2012, 6 Suppl 1(Suppl 1):S63-74.

32. Altman DG, Bland JM: How to obtain the confidence interval from a P value. Bmj 2011, 343:d2090.

33. Sun C, Mezzadra R, Schumacher TN: Regulation and Function of the PD-L1 Checkpoint. Immunity 2018, 48(3):434-452.

34. Frenel JS, Le Tourneau C, O'Neil B, Ott PA, Piha-Paul SA, Gomez-Roca C, van Brummelen EMJ, Rugo HS, Thomas S, Saraf S et al: Safety and Efficacy of Pembrolizumab in Advanced, Programmed Death Ligand 1-Positive Cervical Cancer: Results From the Phase Ib KEYNOTE-028 Trial. J Clin Oncol 2017 , 35(36):4035-4041.

35. Morris VK, Salem ME, Nimeiri H, Iqbal S, Singh P, Ciombor K, Polite B, Deming D, Chan E, Wade JL et al: Nivolumab for previously treated unresectable metastatic anal cancer (NCI9673): a multicentre, single-arm, phase 2 study. Lancet Oncol 2017, 18(4):446-453.

36. McGregor B, Sonpavde G: Immunotherapy for advanced penile cancer - rationale and potential. Nat Rev Uro/ 2018, 15(12):721-723.

37. Seiwert TY, Burtness B, Mehra R, Weiss J, Berger R, Eder JP, Heath K, McClanahan T, Lunceford J, Gause C et al: Safety and clinical activity of pembrolizumab for treatment of recurrent or metastatic squamous cell carcinoma of the head and neck (KEYNOTE-012): an open-label, multicentre, phase 1b trial. Lancet Oncol 2016, 17(7):956-965.

38. Ock CY, Keam B, Kim S, Lee JS, Kim M, Kim TM, Jeon YK, Kim DW, Chung DH, Heo DS: Pan-Cancer Immunogenomic Perspective on the Tumor Microenvironment Based on PD-L1 and CD8 T-Cell Infiltration. Clin Cancer Res 2016, 22(9):2261-2270.

39. Herfs M, Roncarati P, Koopmansch B, Peulen O, Bruyere D, Lebeau A, Hendrick E, Hubert P, Poncin A, Penny W et al: A dualistic model of primary anal canal adenocarcinoma with distinct cellular origins, etiologies, inflammatory microenvironments and mutational signatures: implications for personalised medicine. Br J Cancer 2018, 118(10):1302-1312.

40. Sznurkowski JJ, Żawrocki A, Biernat W: Local immune response depends on p16INK4a status of primary tumor in vulvar squamous cell carcinoma. Oncotarget 2017, 8(28):46204-46210.

41. McDaniel AS, Hovelson DH, Cani AK, Liu CJ, Zhai Y, Zhang Y, Weizer AZ, Mehra R, Feng FY, Alva AS et al: Genomic Profiling of Penile Squamous Cell Carcinoma Reveals New Opportunities for Targeted Therapy. Cancer Res 2015, 75(24):5219-5227.

\section{Tables}

Table. 1: Detailed characteristics of the studies included in this meta-analysis. 


\begin{tabular}{|c|c|c|c|c|c|c|c|c|c|c|c|c|}
\hline First author & Year & $\begin{array}{l}\text { Cancer } \\
\text { type }\end{array}$ & Country & Gender & $\begin{array}{l}\text { Age(yr) } \\
\text { (mean/ } \\
\text { median) }\end{array}$ & $\begin{array}{l}\text { Follow- } \\
\text { up(mo) } \\
\text { (mean/ } \\
\text { median }\end{array}$ & No.pts & Pathology & $\begin{array}{l}\text { HPV } \\
\text { detection } \\
\text { method }\end{array}$ & $\begin{array}{l}\text { PD-L1 } \\
\text { distribution }\end{array}$ & $\begin{array}{l}\text { Cutoff } \\
\text { value }\end{array}$ & $\begin{array}{l}\mathrm{PI} \\
\mathrm{pc} \\
\mathrm{p \epsilon}\end{array}$ \\
\hline $\begin{array}{l}\text { Govindarajan } \\
\mathrm{R}^{5}\end{array}$ & 2016 & $\begin{array}{l}\text { anal } \\
\text { cancer }\end{array}$ & USA & $\begin{array}{l}\text { male } \\
\text { and } \\
\text { female }\end{array}$ & 52 & NR & 41 & $\mathrm{SCC}$ & P16هIHC》 & mem/cyt & NR & $5 t$ \\
\hline Zhao $\mathrm{YJ}^{6}$ & 2018 & $\begin{array}{l}\text { anal } \\
\text { cancer }\end{array}$ & China & $\begin{array}{l}\text { male } \\
\text { and } \\
\text { female }\end{array}$ & 52.5 & 40.9 & 26 & $\mathrm{SCC}$ & P16هIHC』 & mem & $5 \%$ & $4 t$ \\
\hline Heeren $\mathrm{AM}^{7}$ & 2016 & $\begin{array}{l}\text { cervical } \\
\text { cancer }\end{array}$ & Netherlands & female & 46 & NR & 156 & SCC & NR & mem/cyt & $5 \%$ & $4 C$ \\
\hline Wang $S^{8}$ & 2018 & $\begin{array}{l}\text { cervical } \\
\text { cancer }\end{array}$ & China & female & 46 & 61.05 & 90 & $\mathrm{SCC}$ & NR & NR & $\begin{array}{l}\mathrm{H}- \\
\text { score }>100\end{array}$ & 5 \\
\hline Udager $\mathrm{AM}^{9}$ & 2016 & $\begin{array}{l}\text { penile } \\
\text { cancer }\end{array}$ & USA & male & 63 & NR & 37 & $\mathrm{SCC}$ & HPV-DNA & mem & $5 \%$ & $6 i$ \\
\hline Deng $C^{10}$ & 2017 & $\begin{array}{l}\text { penile } \\
\text { cancer }\end{array}$ & China & male & 53 & NR & 116 & $\mathrm{SCC}$ & NR & mem & $5 \%$ & $5 i$ \\
\hline $\begin{array}{l}\text { Ottenhof } \\
\mathrm{SR}^{\ddagger}, 11,12\end{array}$ & 2018 & $\begin{array}{l}\text { penile } \\
\text { cancer }\end{array}$ & Netherlands & male & 65.9 & 100.7 & 213 & $\mathrm{SCC}$ & HPV-DNA & mem & $1 \%$ & $4 \varepsilon$ \\
\hline Howitt $\mathrm{BE}^{13}$ & 2016 & $\begin{array}{l}\text { vulvar } \\
\text { cancer }\end{array}$ & USA & female & 69 & NR & 23 & SCC & $\mathrm{IHC}$ & mem/ cyt & 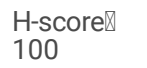 & $3 !$ \\
\hline $\begin{array}{l}\text { Sznurkowski } \\
\mathrm{JJ}^{14}\end{array}$ & 2017 & $\begin{array}{l}\text { vulvar } \\
\text { cancer }\end{array}$ & Poland & female & 68 & NR & 84 & $\mathrm{SCC}$ & P16 & mem & $5 \%$ & $3 ;$ \\
\hline Hecking $T^{15}$ & 2017 & $\begin{array}{l}\text { vulvar } \\
\text { cancer }\end{array}$ & Germany & female & 64 & 46.7 & 103 & $\mathrm{SCC}$ & SIH/P16 & mem & $9.70 \%$ & $2 i$ \\
\hline $\begin{array}{l}\text { Choschzick } \\
M^{16}\end{array}$ & 2018 & $\begin{array}{l}\text { vulvar } \\
\text { cancer }\end{array}$ & Switzerland & female & 68.9 & NR & 55 & $\mathrm{SCC}$ & $\mathrm{SIH}$ & mem & $5 \%$ & $2 i$ \\
\hline Ukpo OC ${ }^{17}$ & 2013 & $\begin{array}{l}\text { oropharynx } \\
\text { cancer }\end{array}$ & USA & $\begin{array}{l}\text { male } \\
\text { and } \\
\text { female }\end{array}$ & 55.8 & NR & 181 & $\mathrm{SCC}$ & P16 & mem+cyt & $5 \%$ & $4 \epsilon$ \\
\hline $\mathrm{Kim} \mathrm{HS}^{18}$ & 2016 & $\begin{array}{l}\text { oropharynx } \\
\text { cancer }\end{array}$ & Korea & $\begin{array}{l}\text { male } \\
\text { and } \\
\text { female }\end{array}$ & 57.5 & 44 & 133 & SCC & P16 & mem & $20 \%$ & $6 \varepsilon$ \\
\hline $\begin{array}{l}\text { De } \\
\text { Meulenaere } \\
\mathrm{A}^{19}\end{array}$ & 2017 & $\begin{array}{l}\text { oropharynx } \\
\text { cancer }\end{array}$ & Belgium & $\begin{array}{l}\text { male } \\
\text { and } \\
\text { female }\end{array}$ & NR & NR & 99 & SCC & ISH & mem/cyt & $5 \%$ & $2 i$ \\
\hline Steuer $\mathrm{CE}^{20}$ & 2018 & $\begin{array}{l}\text { oropharynx } \\
\text { cancer }\end{array}$ & Georgia & $\begin{array}{l}\text { male } \\
\text { and } \\
\text { female }\end{array}$ & 59 & NR & 97 & $\mathrm{SCC}$ & P16 & mem/cyt & $\begin{array}{l}\text { H-score:1- } \\
130\end{array}$ & $2 !$ \\
\hline $\begin{array}{l}\text { Fukushima } \\
Y^{21}\end{array}$ & 2018 & $\begin{array}{l}\text { oropharynx } \\
\text { cancer }\end{array}$ & Japan & $\begin{array}{l}\text { male } \\
\text { and } \\
\text { female }\end{array}$ & NR & 36 & 92 & SCC & NR & mem/cyt & $1 \%$ & $7 !$ \\
\hline Hong $\mathrm{AM}^{22}$ & 2019 & $\begin{array}{l}\text { oropharynx } \\
\text { cancer }\end{array}$ & Australia & $\begin{array}{l}\text { male } \\
\text { and } \\
\text { female }\end{array}$ & 59 & NR & 214 & $\mathrm{SCC}$ & $\begin{array}{l}\text { P16/HPV- } \\
\text { DNA }\end{array}$ & mem & $1 \%$ & $6 i$ \\
\hline Sato $F^{23}$ & 2019 & $\begin{array}{l}\text { oropharynx } \\
\text { cancer }\end{array}$ & Japan & $\begin{array}{l}\text { male } \\
\text { and } \\
\text { female }\end{array}$ & 63 & 37 & 137 & $\mathrm{SCC}$ & NR & mem/cyt & $5 \%$ & $5 !$ \\
\hline $\begin{array}{l}\text { Lyford-Pike } \\
S^{24}\end{array}$ & 2013 & $\begin{array}{l}\text { tonsil } \\
\text { cancer }\end{array}$ & USA & NR & NR & NR & 27 & $\mathrm{SCC}$ & $\mathrm{ISH} / \mathrm{IHC}$ & mem & $5 \%$ & $7 c$ \\
\hline Kwon $\mathrm{MJ}^{25}$ & 2018 & $\begin{array}{l}\text { tonsil } \\
\text { cancer }\end{array}$ & Korea & $\begin{array}{l}\text { male } \\
\text { and } \\
\text { female }\end{array}$ & NR & NR & 79 & SCC & Chip test & mem/cyt & $5 \%$ & $2 !$ \\
\hline
\end{tabular}

mo: month; yr: year; NR: not report; No.pts : number of patients; SCC: squamous cell carcinoma; OS: overall survival; CSS: cancer specific survival; DFS: disease free survival; U: univariate analysis; M: multivariate analysis; SC: survival curves; NOS: Newcastle-Ottawa Scale; ISH: in situ hybridization; IHC: immunohistochemistry;

mem/cyt: PD-L1 positivity was defined as tumor cell membranous and/or cytoplasmic staining; mem: PD-L1 positivity was defined as tumor cell membranous staining; 
mem+cyt: PD-L1 positivity was defined as tumor cell membranous and cytoplasmic staining;

t: $95 \% \mathrm{Cl}$ was calculated by method described by Altman et al, when its HR and P value were provided in the study.

‡: two studies shared this patient population. Only HR and 95\% Cl of CSS (diffuse vs negative/margin PD-L1 tumor-cell expression) were extracted from one study.

Table 2. Association between PD-L1 in tumor cells and clinicopathological characteristics in HPV-related SCC.

\begin{tabular}{|c|c|c|c|c|c|c|}
\hline \multicolumn{7}{|l|}{ Anogenital SCC } \\
\hline \multirow[t]{2}{*}{ Clinical parameters } & \multirow{2}{*}{$\begin{array}{l}\text { Number of studies (number of } \\
\text { patients) }\end{array}$} & \multirow[t]{2}{*}{ OR $(95 \% \mathrm{Cl})$} & \multirow[t]{2}{*}{ Model } & \multicolumn{2}{|c|}{ Heterogeneity } & \multirow{2}{*}{$\begin{array}{l}\text { Significance } \\
(P)\end{array}$} \\
\hline & & & & $P^{2}$ & $P$ & \\
\hline Gender (Male VS Female) & $2(67)$ & $0.32(0.10-1.01)$ & Fixed & $0.0 \%$ & 0.979 & 0.052 \\
\hline Age (Old VS young) ${ }^{+}$ & $5(292)$ & $1.63(1.04-2.58)$ & Fixed & $45.6 \%$ & 0.118 & 0.035 \\
\hline T stage ( T3/T4 VS T1/T2) & $4(397)$ & $1.25(0.74-2.11)$ & Fixed & $20.1 \%$ & 0.289 & 0.400 \\
\hline Grade ( G3 VS G1/G2) & $4(318)$ & $2.49(1.39-4.46)$ & Fixed & $0.0 \%$ & 0.790 & 0.002 \\
\hline $\begin{array}{l}\text { Lymph node metastases ( Present VS } \\
\text { Absent) }\end{array}$ & $7(627)$ & $1.85(1.28-2.66)$ & Fixed & $32.9 \%$ & 0.177 & 0.001 \\
\hline Distant Metastases (Present VS Absent) & $2(140)$ & $\begin{array}{l}5.31(0.97- \\
28.96)\end{array}$ & Fixed & $0.0 \%$ & 0.414 & 0.054 \\
\hline Recurrence (Present VS absent) & $2(78)$ & $2.48(0.70-8.83)$ & Fixed & $0.0 \%$ & 0.739 & 0.161 \\
\hline \multicolumn{7}{|l|}{ Oropharynx SCC } \\
\hline Gender (Male VS Female) & $6(843)$ & $0.39(0.14-1.07)$ & Random & $74.8 \%$ & 0.001 & 0.067 \\
\hline Age (Old VS young) $)^{\ddagger}$ & $3(349)$ & $0.60(0.37-0.98)$ & Fixed & $17.5 \%$ & 0.298 & 0.042 \\
\hline T stage (T3/T4 VS T1/T2) & $6(843)$ & $0.96(0.71-1.30)$ & Fixed & $7.6 \%$ & 0.368 & 0.796 \\
\hline Grade (G3 VS G1/G2) & $3(315)$ & $3.40(1.81-6.40)$ & Fixed & $0.0 \%$ & 0.389 & 0.000 \\
\hline $\begin{array}{l}\text { Lymph node metastases (Present VS } \\
\text { Absent) }\end{array}$ & $5(706)$ & $1.97(1.32-2.92)$ & Fixed & $30.5 \%$ & 0.218 & 0.001 \\
\hline
\end{tabular}

t: Cut-off value of age included in meta-analysis were $37,46,52,53,65$ or 73 years old respectively.

¥: Cut-off value of age included in meta-analysis were 60,63 or 65 years old respectively.

\section{Figures}




\begin{tabular}{|} 
Records identified through searching \\
Pubmed $(\mathrm{n}=137)$ \\
Embase $(\mathrm{n}=413)$ \\
Cochrane $(\mathrm{n}=20)$
\end{tabular}

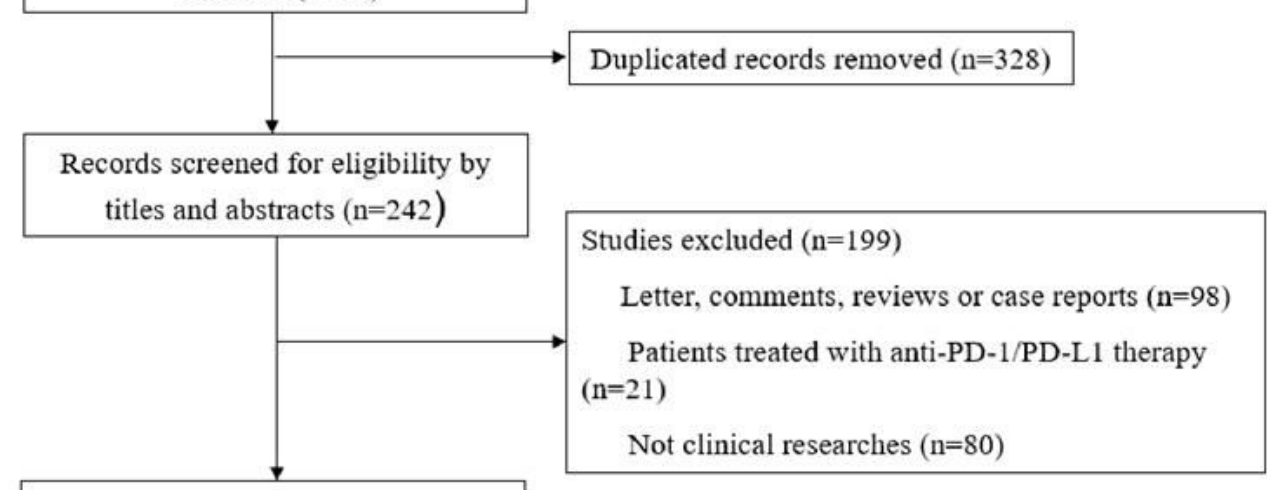

Full-text articles assessed for eligibility $(n=43)$

Full-text articles excluded with reasons $(n=23)$

$$
\text { Insufficient data }(\mathrm{n}=10)
$$

PD- $\mathrm{L} 1$ expressing in non-cancer cells $(\mathrm{n}=7)$

Not squamous cell carcinoma $(n=5)$

Only including P16 positive patients $(n=1)$

Studies enrolled in meta-analysis and systematic review $(\mathrm{n}=20)$

\section{Figure 1}

Study selection process.

\begin{tabular}{|} 
Records identified through searching \\
Pubmed $(\mathrm{n}=137)$ \\
Embase $(\mathrm{n}=413)$ \\
Cochrane $(\mathrm{n}=20)$
\end{tabular}

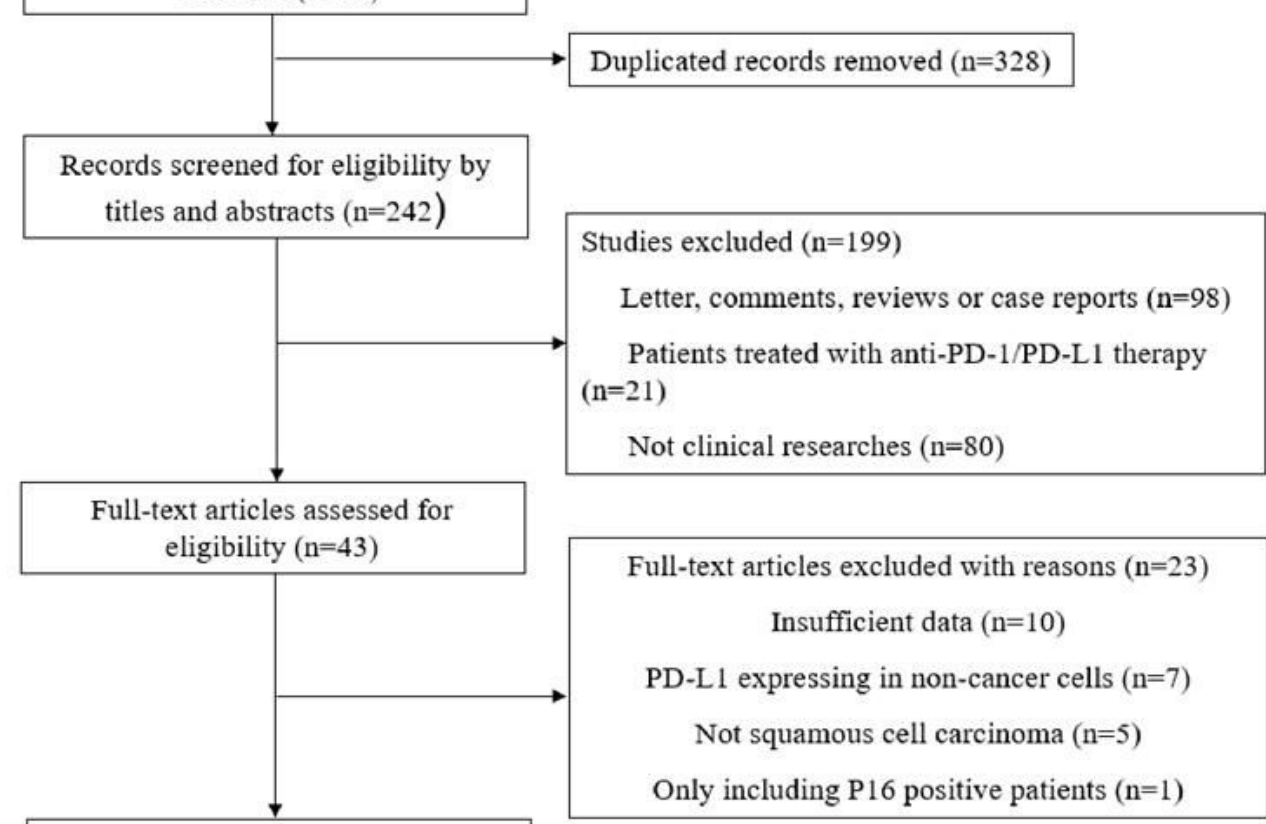

Studies enrolled in meta-analysis and systematic review $(\mathrm{n}=20)$ 
Figure 1

Study selection process.

a Study

ID

Heeren AM (2016)

Zhao YJ (2016)

Howitt BE (2016)

Ottenhof SR (2017)

Choschzick M (2017)

Hecking T (2018)

Govindarajan R (2018)

A. M. Udager (2018)

Overall (I-squared $=10.4 \%, p=0.349$ )

$\stackrel{1}{\text { soss }}$
$\%$

OR $(95 \% \mathrm{Cl}) \quad$ Weight

$0.51(0.23,1.14) \quad 24.67$

$0.23(0.04,1.54) \quad 6.64$

$0.05(0.00,1.08) \quad 8.20$

$0.50(0.26,0.96) \quad 37.42$

$1.58(0.44,5.76) \quad 5.26$

$0.09(0.00,1.50) \quad 9.60$

$1.24(0.07,21.24) 1.22$

$0.47(0.11,2.10) \quad 6.99$

$0.47(0.31,0.71) \quad 100.00$ b

ID

Lyford-Pike S (2013)

Ukpo OC (2013)

Kim HS (2016)

De Meulenaere A (2017)

Steuer CE (2018)

Kwon MJ (2018)

Fukushima Y (2018)

Hong AM (2019)

Overall (l-squared $=55.6 \%, p=0.027$ )

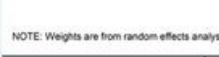

OR $(95 \% \mathrm{Cl}) \quad$ Weight

$>5.83(0.87,38.94) \quad 5.80$

$1.11(0.53,2.36) \quad 16.04$

$1.53(0.71,3.26) \quad 15.92$

$11.00(3.37,35.87) \quad 10.81$

$3.56(0.96,13.19) \quad 9.60$

$2.74(1.01,7.44) \quad 12.83$

$3.68(1.29,10.48) \quad 12.27$

$4.31(2.14,8.71) \quad 16.72$

$3.01(1.78,5.09) \quad 100.00$

\section{Figure 2}

Forest plots for the association between PD-L1 expression and HPV status in anogenital and oropharyngeal SCC. (A) Association between PD-L1 expression and HPV status in anogenital SCC. (B) Association between PD-L1 expression and HPV status in oropharyngeal SCC.

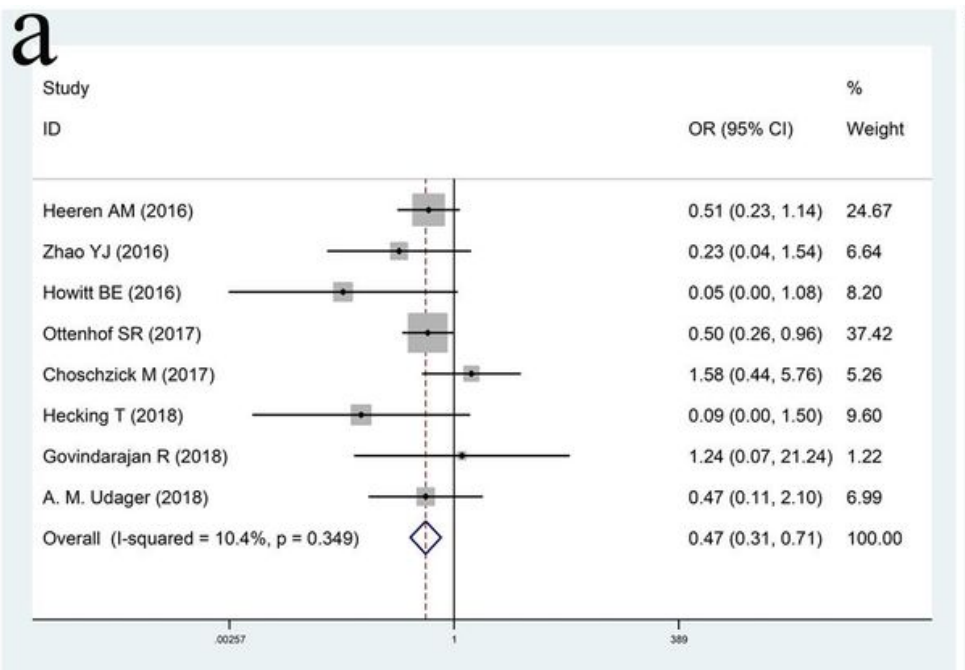

b

ID
$\%$

OR $(95 \% \mathrm{Cl}) \quad$ Weight

Lyford-Pike S (2013)

Ukpo OC (2013)

Kim HS (2016)

De Meulenaere A (2017)

Steuer CE (2018)

Kwon MJ (2018)

Fukushima $Y$ (2018)

Hong AM (2019)

Overall (1-squared $=55.6 \%, p=0.027$ )
$>5.83(0.87,38.94) \quad 5.80$

$1.11(0.53,2.36) \quad 16.04$

$1.53(0.71,3.26) \quad 15.92$

$11.00(3.37,35.87) \quad 10.81$

$3.56(0.96,13.19) \quad 9.60$

$2.74(1.01,7.44) \quad 12.83$

$3.68(1.29,10.48) \quad 12.27$

$4.31(2.14,8.71) \quad 16.72$

$3.01(1.78,5.09) \quad 100.00$

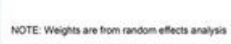

Figure 2

Forest plots for the association between PD-L1 expression and HPV status in anogenital and oropharyngeal SCC. (A) Association between PD-L1 expression and HPV status in anogenital SCC. (B) Association between PD-L1 expression and HPV status in oropharyngeal SCC. 
a

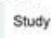

ID

Ju Sznurkowsoi (2017)

Hecking T (2017)

Wang $S$ (2018)

Zhao YJ (2018)

Choschrick M (2018)

Overall (l-squared $=0.0 \%, p=0.569$ )

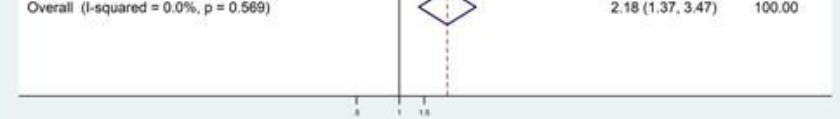

$\mathrm{c}$

ID

Ukpo OC (2013)

Kim HS (2016)

De Meulenaere A (2017)

Stever CE (2018)

Kwon MJ (2018)

Fukushima $Y$ (2018)

Hong AM (2019)

Sato $F$ (2019)

Overall (1-squared $=0.0 \%, p=0.480$ )
$\%$

"HR" $(95 \% \mathrm{Cl}) \quad$ Weight

$2.18(1.01,4.12) \quad 43.57$

$2.22(0.93 .5 .32) \quad 28.25$

$6.07(1.36,26.97) \quad 9.67$

$18210.12 .2708)(293$

$1.16(0.36,3.78) \quad 15.58$

$2.18(1.37,3.47) \quad 100.00$
$0.91(0.54,1.54) \quad 20.08$

$0.81(0.36,1.86) \quad 8.22$

$0.98(0.35,2.74) \quad 5.31$

$1.06(0.61,3.01) \quad 8.83$

$0.26(0.09,0.71) \quad 5.30$

$0.54(0.23,1.30) \quad 7.35$

$0.70(0.46,1.07) \quad 31.58$

$0.92(0.48,1.76) \quad 13.33$

$0.76(0.60,0.97) \quad 100.00$ $\mathrm{b}$

10
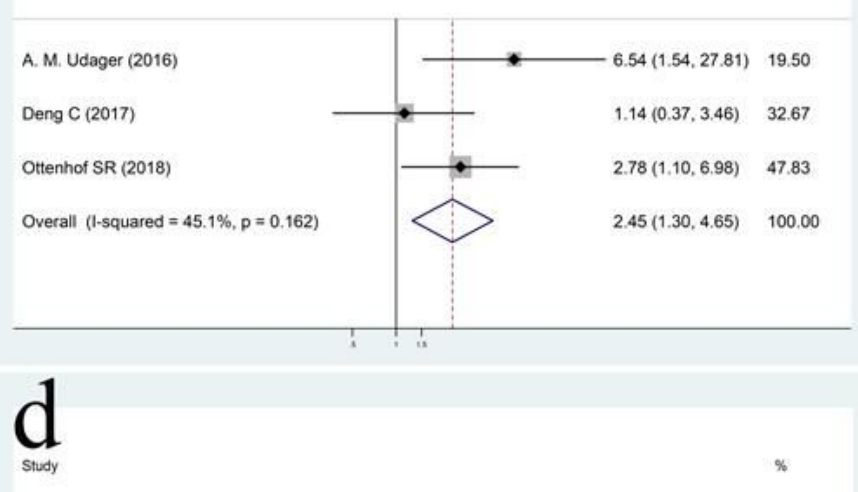

ID

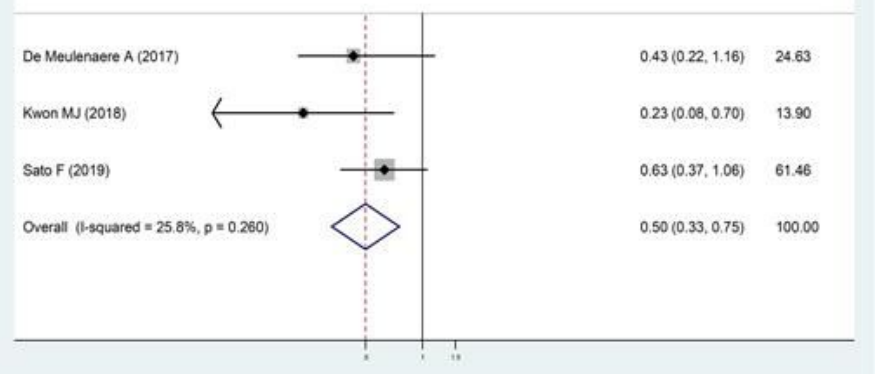

\section{Figure 3}

Forest plots for the association between PD-L1 expression and oncological prognosis in in anogenital and oropharyngeal SCC. (A) OS of anogenital SCC. (B) CSS of penile SCC. (C) OS of oropharyngeal SCC. (D) DFS of oropharyngeal SCC. 
a

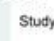

id

Ju Sznurkowski (2017)

Hecking T (2017)

Wang $\mathrm{S}$ (2018)

Zhao YJ (2018)

Choschiock M (2018)

Overall (l-squared $=0.0 \%, p=0.569$ )

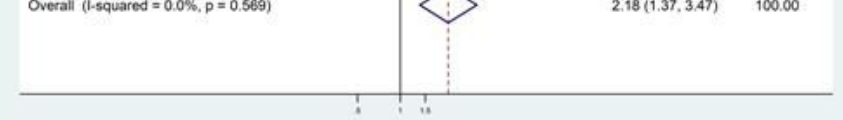

c

ID

Ukpo OC (2013)

Kim HS (2016)

De Meulenaere A (2017)

Stever CE (2018)

Kwon MJ (2018)

Fukushima $Y$ (2018)

Hong AM (2019)

Sato F (2019)

Overall (1-squared $=0.0 \%, p=0.480$ )
$\%$

"HR' $(95 \% \mathrm{Cl}) \quad$ Weight

$2.18(1.01,4.12) \quad 43.57$

$2.22(0.93 .5 .32) \quad 28.25$

$6.07(1.36,26.97) \quad 9.67$

$1.82(0.12 .27 .06) \quad 2.93$

$1.16(0.36,3.78) \quad 15.58$

$2.18(1.37,3.47) \quad 100.00$
$0.91(0.54,1.54) \quad 20.08$

$0.81(0.36,1.86) \quad 8.22$

$0.98(0.35,2.74) \quad 5.31$

$1.06(0.61,3.01) \quad 8.83$

$0.26(0.09,0.71) \quad 5.30$

$0.54(0.23,1.30) \quad 7.35$

$0.70(0.46,1.07) \quad 31.58$

$0.92(0.48,1.76) \quad 13.33$

$0.76(0.60,0.97) \quad 100.00$ b

ID

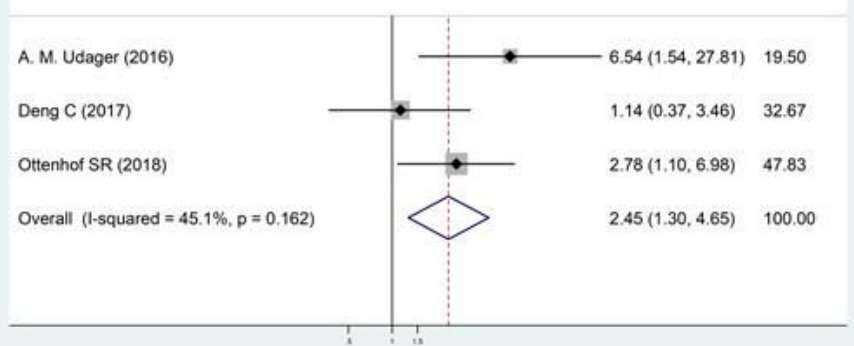

d
ID

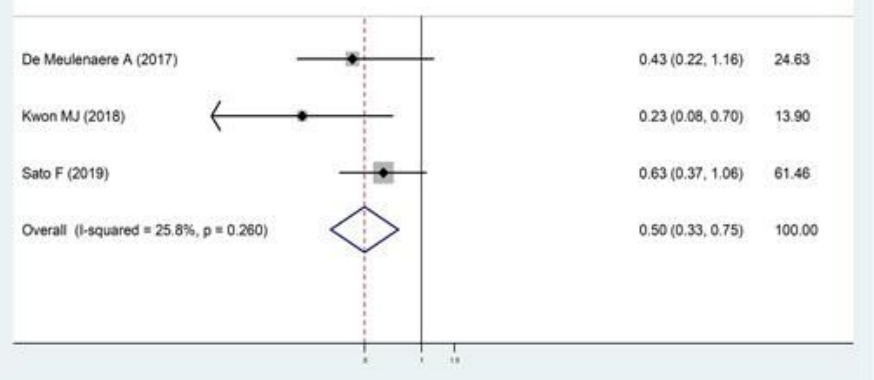

\section{Figure 3}

Forest plots for the association between PD-L1 expression and oncological prognosis in in anogenital and oropharyngeal SCC. (A) OS of anogenital SCC. (B) CSS of penile SCC. (C) OS of oropharyngeal SCC. (D) DFS of oropharyngeal SCC.

\section{Supplementary Files}

This is a list of supplementary files associated with this preprint. Click to download.

- tableS3.docx

- tables3.docx

- tables2.doc

- tables2.doc

- tables1.doc

- tables1.doc 